\title{
N-Succinyl-S-Farnesyl-L-Cysteine (SFC): A Novel Isoprenylcysteine Analog with In Vitro Anti-Inflammatory Activity and Clinical Skin Protecting Properties
}

\author{
José R. Fernández $^{1}$, Karl Rouzard ${ }^{1}$, Corey Fitzgerald ${ }^{1}{ }^{\mathbb{D}}$, Jason Healy ${ }^{1}$, Masanori Tamura ${ }^{1}$, Michael Voronkov ${ }^{1}$, \\ Jeffry B. Stock ${ }^{2}$, Maxwell Stock ${ }^{1}$ and Eduardo Pérez ${ }^{1, * \mathbb{D}}$ \\ 1 Signum Biosciences, 11 Deer Park Drive, Suite 202, Monmouth Junction, NJ 08852, USA; \\ jfernandez@signumbio.com (J.R.F.); krouzard@signumbio.com (K.R.); cwebb@signumbio.com (C.F.); \\ jhealy@signumbio.com (J.H.); mtamura@signumbio.com (M.T.); mvoronkov@signumbio.com (M.V.); \\ mstock@signumbio.com (M.S.) \\ 2 Department of Molecular Biology, Princeton University, Princeton, NJ 08540, USA; jstock@princeton.edu \\ * Correspondence: eperez@signumbio.com; Tel.: +1-732-329-6344
}

check for updates

Citation: Fernández, J.R.; Rouzard, K.; Fitzgerald, C.; Healy, J.; Tamura, M.; Voronkov, M.; Stock, J.B.; Stock, M.; Pérez, E.

N-Succinyl-S-Farnesyl-L-Cysteine (SFC): A Novel Isoprenylcysteine Analog with In Vitro

Anti-Inflammatory Activity and Clinical Skin Protecting Properties. Cosmetics 2021, 8, 110. https:// doi.org/10.3390/cosmetics8040110

Academic Editor: Isabel Martins de Almeida

Received: 2 November 2021

Accepted: 18 November 2021

Published: 20 November 2021

Publisher's Note: MDPI stays neutral with regard to jurisdictional claims in published maps and institutional affiliations.

Copyright: (c) 2021 by the authors. Licensee MDPI, Basel, Switzerland. This article is an open access article distributed under the terms and conditions of the Creative Commons Attribution (CC BY) license (https:/ / creativecommons.org/licenses/by/ $4.0 /)$.

\begin{abstract}
Over the past 15 years, small molecule isoprenylcysteine (IPC) analogs have been identified as a potential new class of topical anti-inflammatories. Clinical studies have demonstrated that IPCs are both safe and effective in promoting healthy skin when applied topically. This work aims to demonstrate N-Succinyl-S-farnesyl-L-cysteine (SFC) as a novel IPC molecule that provides a broad spectrum of benefits for skin. Human promyelocytic cell line HL-60, human dermal microvascular endothelial cells (HDMECs), human dermal fibroblasts (HDFs), and normal human epidermal keratinocytes (NHEKs) were exposed in culture to various inducers to trigger reactive oxygen species, cytokines, or collagenase production. A 49-subject randomized double-blind, vehicle-controlled, split face trial was performed with $1 \%$ SFC gel, or $5 \%$ niacinamide and vehicle applied for 12 weeks to evaluate anti-wrinkle and anti-aging endpoints. We demonstrated that SFC inhibited GPCR and TLR-induced pro-inflammatory cytokine release in NHEKs and HDMECs from several inflammatory inducers such as UVB, chemicals, cathelicidin, and bacteria. SFC successfully reduced GPCR-induced oxidation in differentiated neutrophils. Moreover, photoaging studies showed that SFC reduced UVA-induced collagenase (pro-MMP-1) production in HDFs. Clinical assessment of $1 \%$ SFC gel demonstrated improvement above the vehicle for wrinkle reduction, hydration, texture, and overall appearance of skin. N-Succinyl-S-farnesyl-L-cysteine (SFC) is a novel anti-inflammatory small molecule and is the first farnesyl-cysteine IPC shown to clinically improve appearance and signs of aging, while also having the potential to ameliorate inflammatory skin disorders.
\end{abstract}

Keywords: isoprenylcysteine; anti-aging; cosmetics; G-protein coupled receptor; toll-like receptor

\section{Introduction}

Small molecule isoprenylcysteine (IPC) analogs have been identified as a potential novel class of topical anti-inflammatories. IPC analogs contain a 15- or 20-carbon side chain attached to the amino acid cysteine, mimicking the C-terminus of processed CAAX proteins, which is essential to membrane targeting of heterotrimeric and small G-proteins that mediate receptor signaling in eukaryotic cells. IPC analogs inhibit signaling activation at the membrane compartment by competing with isoprenoid groups for prenyl-binding sites $[1,2]$ and by disrupting signal transduction by preventing heterotrimeric G-protein formation and/or presumably by blocking downstream G-protein-effector interactions [3-5].

Since the initial discovery of N-Acetyl-S-farnesyl-L-cysteine (AFC) as the first IPC analog to effectively downregulate inflammatory responses in platelets, macrophages, and neutrophils [6-8], several different IPC analogs have been discovered and reported to provide a variety of different activities in skin, including inhibiting G-protein coupled receptor 
(GPCR)-induced pro-inflammatory cytokine release, edema, and neutrophil infiltration when applied topically [9]. For instance, N-acetylglutaminoyl-S-farnesyl-L-cysteine (SIG1191) demonstrates anti-inflammatory and hydration properties in human keratinocytes and human 3D skin [10]. More recent studies demonstrate that IPC analogs also downregulate non-G-protein mediated inflammation in human epidermal keratinocytes, human dermal fibroblasts, human dermal endothelial cells, and peripheral blood mononuclear cells by abrogating toll-like receptors 2, 4, and 6 (TLR2, TLR4, TLR6) and T-cell receptor (TCR) signaling [11,12]. Furthermore, phytyl-cysteine IPC analogs have also been shown to be clinically effective against acne [13] and skin aging [14], highlighting the effectiveness of this class of compounds in blocking cutaneous inflammation, and improving different skin conditions when applied topically.

Here, we report that novel IPC analog N-Succinyl-S-farnesyl-L-cysteine (SFC) (Figure S1) possesses a broad range of anti-inflammatory and skin protecting properties to help slow inflammation and aging by a previously unknown mechanism of action. Studies utilizing dermal endothelial cells show that SFC inhibits cathelicidin (LL-37) GPCR-induced inflammation. Moreover, in vitro studies in epidermal keratinocytes demonstrate that SFC successfully inhibits pro-inflammatory cytokine release from several environmental stressors such as UVB, chemicals, and bacteria. Photoaging studies show that SFC can successfully reduce UVA-induced collagenase (pro-MMP-1) production in dermal fibroblasts. Given this multifunctional activity profile in skin, we then tested SFC clinically in a split face, double-blind, vehicle-controlled study, and demonstrated that $1 \%$ SFC gel is well tolerated and significantly outperforms vehicle showing significant improvement in all clinical endpoints, including wrinkle reduction, hydration, and overall appearance of skin.

\section{Materials and Methods}

\subsection{Chemicals and Reagents}

All reagents were purchased from Sigma Chemical Co. (St. Louis, MO, USA). Organic solvents were purchased from Fisher Scientific (Hampton, NH, USA). SFC was synthesized according to methods as described in US patent US10314802B2. All chemicals were analyzed by LC/MS (Agilent 1100), ${ }^{1} \mathrm{H}$, and ${ }^{13} \mathrm{C}$ NMR $(500 \mathrm{MHz}$ and $125 \mathrm{MHz}$, Bruker) for structural identity, and confirmed to be $>95 \%$ pure by analytical HPLC (Agilent 1200).

\subsection{Cell Treatments}

HL-60 cells (CCL-240 ${ }^{\mathrm{TM}}$ ) were obtained from the American Type Culture Collection (ATCC; Manassas, VA, USA), grown in suspension culture, and induced to differentiate into mature myeloid forms (dHL-60) by cultivation in the presence of $1.3 \%(v / v)$ dimethyl sulfoxide (DMSO) [15]. Burst assay was performed as described previously [16]. Briefly, dHL-60 $\left(2 \times 10^{6}\right.$ cells $\left./ \mathrm{mL}\right)$ were incubated with formyl-Met-Leu-Phe-OH (fMLP) to induce superoxide release from neutrophils. The detection of superoxide anion was measured by the reduction of ferricytochrome $\mathrm{c}$ to ferro-cytochrome $\mathrm{c}$ by reading the absorbance at $550 \mathrm{~nm}$. The assay reaction mixture was prepared in Hanks' Balanced Salt Solution (HBSS) with $160 \mu \mathrm{M}$ cytochrome c, $100 \mathrm{U} / \mathrm{mL}$ superoxide dismutase (SOD), and $16 \mu \mathrm{M}$ TPA (12-O-Tetradecanoylphorbol 13-acetate). Absorbance was measured in a plate reader at $550 \mathrm{~nm}$ as the endpoint (after 20 min exposure).

Human primary cells obtained from neonatal donors were purchased from ThermoFisher (NHEKs, HDFs; Carlsbad, CA, USA) and ScienCell (HDMECs; Carlsbad, CA, USA). Cells $\left(1 \times 10^{6}\right.$ cells $\left./ \mathrm{mL}\right)$ were grown at normal conditions $\left(5 \% \mathrm{CO}_{2} ; 37^{\circ} \mathrm{C}\right)$, and later pre-incubated for $2 \mathrm{~h}$ with compounds $(0.1 \% v / v$ ethanol vehicle) in growth factordepleted fresh media in triplicates. NHEKs were induced by $5 \mathrm{ng} / \mathrm{mL} \mathrm{TPA}, 25 \mathrm{~mJ} / \mathrm{cm}^{2}$ broadband $305 \pm 12 \mathrm{~nm}$ UVB (Daavlin; Bryan, OH, USA) or $10 \mu \mathrm{g} / \mathrm{mL}$ peptidoglycan. HDMECs and HDFs were induced with $10 \mu \mathrm{g} / \mathrm{mL}$ of LL-37 (Tocris Bioscience; Bristol, UK) and $12.5 \mathrm{~J} / \mathrm{cm}^{2}$ broadband $350 \pm 12 \mathrm{~nm}$ UVA (Daavlin; Bryan, $\mathrm{OH}, \mathrm{USA}$ ), respectively. Cells were subjected to viability tests by tetrazolium compound [3-(4,5-dimethylthiazol-2yl)-5-(3-carboxymethoxyphenyl)-2-(4-sulfophenyl)-2H-tetrazolium, inner salt; MTS] assay 
(Promega; Madison, WI, USA). Media supernatants were harvested after $24 \mathrm{~h}$ induction for cytokines (TNF- $\alpha$, IL-6, IL-8) and collagenase (pro-MMP-1) measurements.

\subsection{Enzyme-Linked Immunosorbent Assays (ELISA)}

The levels of human cytokines and collagenase were measured from tissue culture media supernatants by sandwich ELISA, using appropriate standards and following the manufacturer's protocols. IL-6 and IL-8 kits were purchased from BD Biosciences (San Jose, CA, USA). Pro-MMP-1 and TNF- $\alpha$ kits were purchased from R\&D Systems Inc. (Minneapolis, MN, USA).

\subsection{Clinical Study}

A clinical trial in healthy volunteers was conducted at SGS Stephens (Study\# C20J156; Tokyo, JP), and written informed consent conforming to International Council for Harmonization (ICH) E6(r2) Section 4.8.10 was obtained from each subject. This was a single center, split face, double-blind vehicle-controlled study with a total of 49 Japanese women completing the 12-week study. Subjects were assigned to one of two treatment cells, in accordance with predetermined randomization. Within each cell, subjects were further randomized to use SFC or niacinamide on one side of the face, and a vehicle control on the other side of the face (cell 1: 31 subjects receiving 1\% SFC gel and vehicle, and cell 2: 18 subjects receiving 5\% niacinamide gel and vehicle) (See Table S1 for full ingredient list). This study was conducted based on the "Guidelines for Evaluation of Anti-Wrinkle Products" by the Japanese Cosmetic Science Society. Subjects applied the test material to the assigned side of the crow's feet area and entire half of the face $2 x$ daily. Subjects performed the first application of the test materials in the clinic after completion of baseline evaluations. Clinical evaluations were conducted at visit one (baseline and 15 min post-application), visit two (week 8) and visit three (week 12). Crow's feet wrinkle conditions were chosen in the mild to moderate range (score 3-5 according to the Japanese Society of Cosmetic Chemists (JSCC) scale where $0=$ none and $7=$ significant deep wrinkles observed). Clinical grading of efficacy parameters was assessed separately on the right and left sides of the global face using a modified Griffiths 10-point scale, with half-point scores assigned as necessary ( 0 -none (best possible condition), 1 to $3=$ mild, 4 to $6=$ moderate, 7 to $9=$ severe (worst possible condition)). Efficacy parameters were graded according to the listed scale anchors in Table 1.

Table 1. Clinical efficacy parameters scale anchors.

\begin{tabular}{|c|c|c|}
\hline Parameter & Grade $=0$ & Grade $=9$ \\
\hline Texture (visual) & $\begin{array}{l}\text { Smooth, even-looking skin } \\
\text { texture, no roughness }\end{array}$ & $\begin{array}{l}\text { Pronounced, extensive visible } \\
\text { skin roughness }\end{array}$ \\
\hline Hydration (visual) & $\begin{array}{l}\text { Skin appears hydrated and } \\
\text { full/rounded w/no scaling } \\
\text { and/or flaking }\end{array}$ & $\begin{array}{l}\text { Skin appears dehydrated and } \\
\text { flattened/shriveled w/severe } \\
\text { scaling and/or flaking }\end{array}$ \\
\hline $\begin{array}{l}\text { Radiance, luminosity, } \\
\text { brightness }\end{array}$ & $\begin{array}{l}\text { Radiant, luminous, or } \\
\text { glowing appearance }\end{array}$ & $\begin{array}{l}\text { Dull/matte and/or sallow } \\
\text { skin appearance }\end{array}$ \\
\hline $\begin{array}{l}\text { Overall appearance of skin } \\
\text { condition (healthy) }\end{array}$ & $\begin{array}{l}\text { Excellent, healthy skin tone } \\
\text { free from skin abnormalities }\end{array}$ & $\begin{array}{l}\text { Poor, unhealthy skin tone; } \\
\text { extensive skin abnormalities }\end{array}$ \\
\hline Texture (tactile) & $\begin{array}{c}\text { Smooth, even-feeling skin } \\
\text { texture }\end{array}$ & $\begin{array}{c}\text { Rough, uneven-feeling skin } \\
\text { texture }\end{array}$ \\
\hline Firmness (tactile) & $\begin{array}{l}\text { Skin feels thick, dense, and } \\
\text { firm }\end{array}$ & Skin feels thin and loose \\
\hline
\end{tabular}

\subsection{Statistical Analysis}

Statistical significance was determined by ANOVA followed by a Dunnett multiple comparisons test using $p$-values less than 0.05 as a significant difference. For all antibacterial 
measurements and cytokine levels, samples were assayed in triplicate. Cytokine doseresponse curves were generated by fitting data with the Hill, three-parameter equation using the Sigma Plot software (Systat Software Inc., Chicago, IL, USA), from which the $\mathrm{IC}_{50}$ and maximum inhibition were determined.

\section{Results}

\subsection{SFC Inhibits GPCR-Induced Oxidative Stress and Inflammation}

Formyl peptide receptor-1 (FPRL1) is a GPCR located on the surface of neutrophils and endothelial cells that plays a critical role in response to a wide number of inflammatory stimuli [17]. For example, N-Formyl Methionyl-leucyl-phenylalanine (fMLP) is a chemotactic peptide that binds to FPRL1 recruiting neutrophils, and upon their arrival, triggers a rapid release of reactive oxygen species (ROS) and a variety of antimicrobial functions [18]. However, if neutrophil recruitment persists, significant dysregulation of the inflammatory cascade occurs, which has implicated neutrophil infiltration in the pathogenesis of rosacea and several other skin diseases [19]. Cathelicidin (LL-37) is another FPRL1 ligand with pleiotropic activity, including antimicrobial properties, recruitment, and inflammation that has been linked to atopic dermatitis, psoriasis, and rosacea [20]. Thus, we sought to investigate if SFC could successfully modulate FPRL1-mediated oxidative burst and inflammation. Using differentiated neutrophils (dHL-60) [21], fMLP was added to initiate ROS, and results show that SFC effectively blocks superoxide formation in a dose-dependent manner $\left(\mathrm{IC}_{50}=25 \mu \mathrm{M}\right.$ ) (Figure 1A) with non-toxic effects (Figure S2). In addition, human dermal microvascular endothelial cells (HDMECs) treated with $10 \mu \mathrm{g} / \mathrm{mL}$ LL-37 induces the overproduction of pro-inflammatory cytokine IL-6. Treatments with SFC inhibited the release of IL-6 dose-dependently by $100 \%$ (Figure 1B) with non-toxic effects (Figure S2) and similar potency $\left(\mathrm{IC}_{50}=2 \mu \mathrm{M}\right)$ to eczema drug FK-506 $\left(\mathrm{IC}_{50}=1 \mu \mathrm{M}\right)$, and significantly better than rosacea treatments metronidazole $\left(\mathrm{IC}_{50}=14 \mu \mathrm{M}\right)$ and azelaic acid $\left(\mathrm{IC}_{50}=100 \mu \mathrm{M}\right)$. Topical glucocorticoid clobetasol exhibited the strongest anti-inflammatory activity as expected $\left(\mathrm{IC}_{50}=0.08 \mu \mathrm{M}\right.$; data not shown).

A

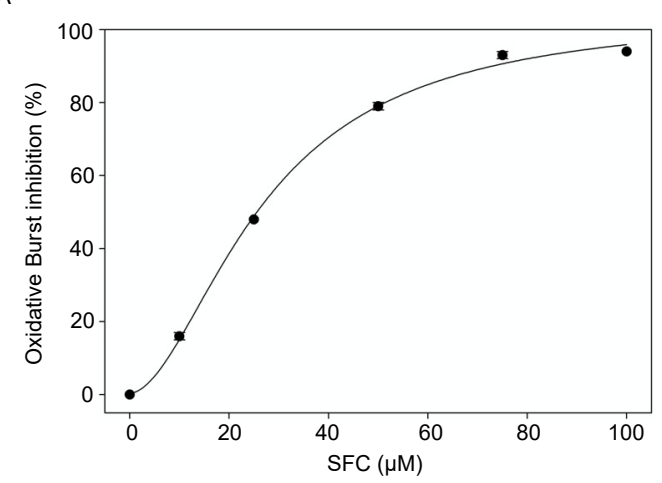

B

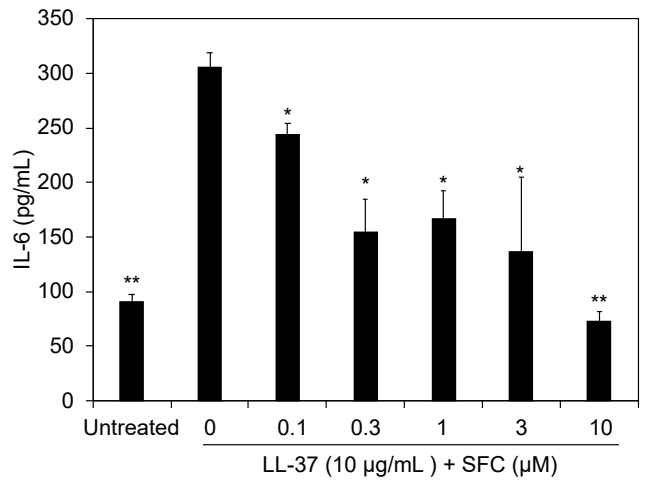

Figure 1. SFC blocks superoxide formation in HL-60 cells and pro-inflammatory cytokines in HDMECs in a dose-dependent manner. (A) HL-60 cells were differentiated with 1.3\% DMSO for five days resulting in differentiated neutrophils (dHL-60). Cells were pre-incubated with SFC for $10 \mathrm{~min}$, then burst initiated with addition of fMLP (200 nM) to induce oxidative burst response (rapid release of ROS). Media supernatants were collected after $24 \mathrm{~h}$, and absorbance measured at $550 \mathrm{~nm}$ and $556.5 \mathrm{~nm}$. $\mathrm{IC}_{50}$ value $(25 \mu \mathrm{M})$ was determined by data fitting using the Hill, three-parameter equation. (B) Primary human dermal microvascular endothelial cells (HDMECs) were co-treated with cathelicidin (LL-37, $10 \mu \mathrm{g} / \mathrm{mL}$ ) and compounds for $24 \mathrm{~h}$. Media supernatants were collected after $24 \mathrm{~h}$ and analyzed by ELISA for Interleukin-6 (IL-6). Data represents mean \pm StDev from three independent experiments. ${ }^{*} p<0.05 ;{ }^{* *} p \leq 0.01$ relative to inducer + vehicle treated cells.

\subsection{SFC Protects against UVA and UVB-Induced Photoaging}

Ultraviolet (UV) light is a common environmental stressor that attacks our skin daily. Longer wavelength UVA (320-400 nm) penetrates deep into the dermis, while shorter wavelength, higher energy, UVB (290-320 nm) primarily affects our epidermis. 
Specifically, UVA induces the secretion of matrix metalloproteinases (MMPs), which play a major role in cutaneous photoaging [22]. MMP-1, also known as interstitial collagenase, breaks down collagen (Type I, II, and III), contributing to the appearance of fine lines and wrinkles. To determine SFC's anti-wrinkle potential, we screened for its ability to reduce UVA-induced pro-MMP-1 release from human dermal fibroblasts (HDFs). SFC dose dependently inhibits pro-MMP-1 production demonstrating exceptional potency with an $\mathrm{IC}_{50}=10 \mathrm{pM}$ (Table 2) with non-toxic effects (Figure S2), while cosmetic anti-aging actives such as ascorbic acid and $\alpha$-tocopherol did not reduce pro-MMP-1 release at the highest concentration level tested (Table 2). Similar to UVA, extended exposure to UVB triggers a cascade of inflammation and production of pro-inflammatory cytokines that play a key role in sun-induced skin aging [23]. Specifically, normal human epidermal keratinocytes exposed to UVB triggers the release of interleukin- 6 (IL-6) and tumor necrosis factor- $\alpha$ $(\mathrm{TNF}-\alpha)$, which have also been linked to dry skin [24]. Our results demonstrate that SFC blocks both IL- 6 and TNF- $\alpha$ release in a dose-dependent manner with $\mathrm{IC}_{50}=10 \mathrm{pM}$ and $100 \mathrm{pM}$, respectively, with non-toxic effects (Figure S2). Moreover, this strong potency was $4-5$ orders of magnitude greater than that observed for ascorbic acid and $\alpha$-tocopherol which also displayed anti-inflammatory properties (Table 2).

Table 2. SFC anti-cytokine and anti-aging effects on UVA and UVB-treated skin cells.

\begin{tabular}{|c|c|c|c|c|c|}
\hline Compound & Inducer & $\begin{array}{l}\text { Pro-MMP1 } \\
\text { IC }_{50}(\mathrm{nM})\end{array}$ & Inducer & $\begin{array}{c}\text { IL-6 } \\
\mathrm{IC}_{50}(\mathrm{nM})\end{array}$ & $\begin{array}{c}\text { TNF- } \alpha \\
\mathrm{IC}_{50}(\mathrm{nM})\end{array}$ \\
\hline SFC & \multirow{3}{*}{ UVA } & 0.01 & \multirow{3}{*}{ UVB } & 0.01 & 0.1 \\
\hline Ascorbic acid & & $>1000$ & & 100 & 100 \\
\hline$\alpha$-tocopherol & & $>1000$ & & 100 & 100 \\
\hline
\end{tabular}

UVA: ultraviolet A rays; Pro-MMP1: pro-matrix metalloproteinase-1; UVB: ultraviolet B rays; IL-6: interleukin-6; $\mathrm{TNF} \alpha$ : tumor necrosis factor alpha. ${ }^{*} \mathrm{IC}_{50}$ : inhibitory concentration at $50 \%$. Results represent average cumulative data from three independent experiments. $\mathrm{IC}_{50}$ values were determined from dose-response curves using a three-parameter logistic curve fit.

\subsection{SFC Protects against Chemical and Bacteria-Induced Inflammation}

In addition to UV rays from sunlight, many other exogenous environmental stressors trigger inflammation in skin, and can accelerate the natural skin aging process if left unprotected. Two such culprits are chemicals and bacteria. 12-O-tetradecanoylphorbol-13-acetate (TPA) is a common chemical irritant used for testing topical in vivo anti-inflammatory activity [9]. Moreover, previous studies demonstrate normal human epidermal keratinocytes (NHEKs) treated with TPA results in increased production of several pro-inflammatory mediators [25,26]. Our cell-based NHEK assay shows consistent significant TPA induction of TNF- $\alpha$, and that SFC inhibits its release in a dose-dependent manner with an $\mathrm{IC}_{50}=0.75 \mu \mathrm{M}$ (maximum inhibition of $70 \%$ ) (Figure $2 \mathrm{~A}$ ) with non-toxic effects (Figure S2). Meanwhile, anti-inflammatory glucocorticoid clobetasol tested at $3 \mu \mathrm{M}$ demonstrates a maximum inhibition of only $58 \%$, suggesting that SFC is more potent in this specific assay.

TLRs play a critical role in skin regulating the innate immune response to pathogens, and TLR2 signaling specifically has been shown to play a key role in the pathogenesis of several dermatological diseases [27]. Peptidoglycan (PGN) is a bacterial cell wall product and toll-like receptor-2 (TLR2) ligand. Our results show that SFC dose-dependently reduces PGN-induced interleukin-8 (IL-8) release in NHEKs with an $\mathrm{IC}_{50}=0.8 \mu \mathrm{M}$, comparable to clobetasol with an $\mathrm{IC}_{50}=1 \mu \mathrm{M}$ (Figure 2B). 
A

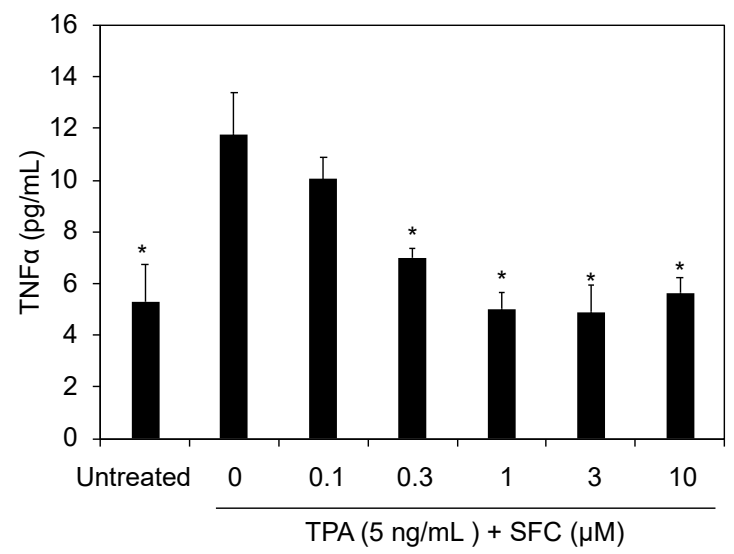

B

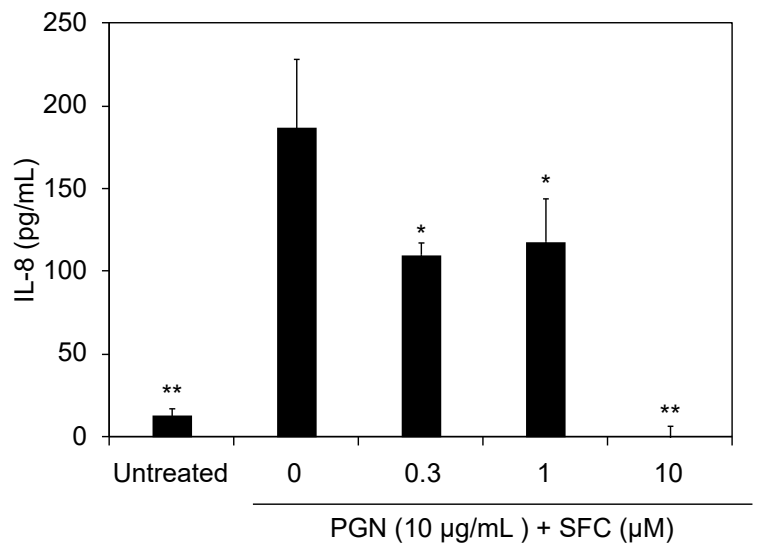

Figure 2. Primary normal human epidermal keratinocytes (NHEKs) were co-treated with (A) 12-O-Tetradecanoylphorbol 13-acetate (TPA, $5 \mathrm{ng} / \mathrm{mL}$ ); (B) peptidoglycan (PGN, $10 \mu \mathrm{g} / \mathrm{mL}$ ) and SFC for $24 \mathrm{~h}$. Media supernatants were collected after $24 \mathrm{~h}$ and analyzed by ELISA for tumor necrosis factor- $\alpha$ (TNF- $\alpha$ ) or Interleukin-8 (IL-8). Data represents mean \pm StDev from three independent experiments. ${ }^{*} p<0.05$; ${ }^{* *} p \leq 0.01$ relative to inducer + vehicle treated cells.

\subsection{SFC Reduces Wrinkles and Improves Several Other Skin Parameters in Human Subjects}

Photoaging of facial skin is one of several factors that contributes to the visual signs of aging, and is characterized by the presence of fine lines, wrinkles, and changes in pigmentation. The data reported here suggests that SFC's in vitro anti-inflammatory, antiaging, and oxidative burst protecting activities could be effective in slowing premature cutaneous aging and inflammation when applied topically to human subjects. Thus, we sought to evaluate SFC clinically to assess its activity upon topical application. SFC was formulated at $1 \%$ in a gel, and was evaluated in a split-face, double blind, vehicle-controlled study, where it was applied twice per day for 12 weeks. Prior to this study, SFC gel was tested in a 100 subject human repeat insult patch test and was found to be safe for skin (data not shown).

A total of 49 women completed the study with all subjects using vehicle on one side of their face, and for the other side, 31 of the subjects used 1\% SFC gel; the remaining 18 subjects used $5 \%$ niacinamide as a comparator, as it has been previously shown to improve facial skin appearance [28]. Results of the clinical grading of wrinkles on the crow's feet area shows statistically significant improvement from baseline and vehicle at weeks 8 and 12 for $1 \%$ SFC gel, while 5\% niacinamide only exhibits significant improvement at week 12 (Figure 3). At week 8, 1\% SFC gel demonstrates a $~ 32 \%$ improvement, while $5 \%$ niacinamide and vehicle only show an $\sim 11 \%$ and $\sim 6 \%$ improvement respectively (Figure 3 ). In addition to wrinkle reduction, $1 \%$ SFC gel significantly outperforms vehicle at several other endpoints, including texture (tactile) and hydration (visual) at weeks 8 and 12, radiance/luminosity/brightness, and texture (visual) at week 12 , and overall appearance of skin condition (healthy) on the face post-application (Table 3). Moreover, in several endpoints $1 \%$ SFC gel not only outperforms vehicle, but also niacinamide. For example, analysis of the radiance/luminosity/brightness parameter at week 12 reveals that subjects using $1 \%$ SFC gel show a statistically significant $~ 52 \%$ improvement compared to only $\sim 22 \%$ for those applying $5 \%$ niacinamide (Table 3). The 1\% SFC gel also significantly outperforms $5 \%$ niacinamide at week 8 for hydration ( 42\% versus $\sim 33 \%$ ) (Table 3$)$. Lastly, for the skin firmness (tactile) endpoint, despite not significantly outperforming vehicle, $1 \%$ SFC gel shows statistically significant improvement of $19 \%$ from baseline ( $p$ value 0.031 ), while the vehicle-only treated skin improved by $\sim 10 \%$ ( $p$ value 0.063 ), and the $5 \%$ niacinamide treated group showed $0 \%$ improvement. Altogether, these results indicate SFC when topically applied clinically improves signs of aging and promotes skin health. 


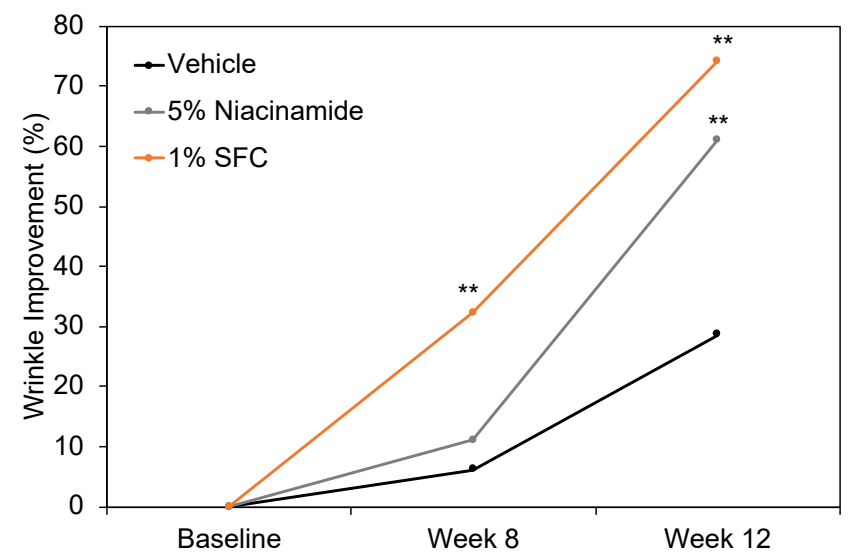

Figure 3. Clinical study utilizing 1\% SFC gel shows improvement in hydration level over vehicletreated skin. The data represent mean $\pm \mathrm{SEM} .{ }^{* *} p \leq 0.01$ indicates a statistically significant difference compared to baseline (week 0 ) reading.

Table 3. Summary of results for clinical grading of activity parameters.

\begin{tabular}{|c|c|c|c|c|}
\hline Endpoint & Treatment & Time Point & $\begin{array}{c}\text { Subject } \\
\text { Improved \% }\end{array}$ & $p$ Value * \\
\hline \multirow{6}{*}{ Texture (visual) } & \multirow[t]{2}{*}{ SFC $1 \%$} & Week 8 & $6.5 \%$ & 1.000 \\
\hline & & Week 12 & $38.7 \%$ & 0.003 \\
\hline & \multirow[t]{2}{*}{ Niacinamide 5\% } & Week 8 & $5.6 \%$ & 1.000 \\
\hline & & Week 12 & $38.9 \%$ & 0.070 \\
\hline & \multirow[t]{2}{*}{ Vehicle } & Week 8 & $2.0 \%$ & 1.000 \\
\hline & & Week 12 & $16.3 \%$ & 0.388 \\
\hline \multirow{9}{*}{$\begin{array}{l}\text { Hydration } \\
\text { (visual) }\end{array}$} & \multirow[t]{3}{*}{ SFC $1 \%$} & Post-application & $90.3 \%$ & $<0.001$ \\
\hline & & Week 8 & $41.9 \%$ & 0.002 \\
\hline & & Week 12 & $80.6 \%$ & $<0.001$ \\
\hline & \multirow[t]{3}{*}{ Niacinamide 5\% } & Post-application & $83.3 \%$ & $<0.001$ \\
\hline & & Week 8 & $33.3 \%$ & 0.289 \\
\hline & & Week 12 & $66.7 \%$ & 0.010 \\
\hline & \multirow[t]{3}{*}{ Vehicle } & Post-application & $87.8 \%$ & $<0.001$ \\
\hline & & Week 8 & $32.7 \%$ & 0.016 \\
\hline & & Week 12 & $59.2 \%$ & $<0.001$ \\
\hline \multirow{9}{*}{$\begin{array}{l}\text { Radiance, } \\
\text { luminosity, } \\
\text { brightness }\end{array}$} & \multirow[t]{3}{*}{ SFC $1 \%$} & Post-application & $45.2 \%$ & $<0.001$ \\
\hline & & Week 8 & $19.4 \%$ & 0.125 \\
\hline & & Week 12 & $51.6 \%$ & $<0.001$ \\
\hline & \multirow[t]{3}{*}{ Niacinamide $5 \%$} & Post-application & $44.4 \%$ & 0.008 \\
\hline & & Week 8 & $0 \%$ & - \\
\hline & & Week 12 & $22.4 \%$ & 0.125 \\
\hline & \multirow[t]{3}{*}{ Vehicle } & Post-application & $40.8 \%$ & $<0.001$ \\
\hline & & Week 8 & $4.1 \%$ & 1.000 \\
\hline & & Week 12 & $24.5 \%$ & 0.003 \\
\hline \multirow{9}{*}{$\begin{array}{c}\text { Overall } \\
\text { appearance of } \\
\text { skin condition } \\
\text { (healthy) }\end{array}$} & \multirow[t]{3}{*}{ SFC $1 \%$} & Post-application & $32.3 \%$ & 0.002 \\
\hline & & Week 8 & $3.2 \%$ & 1.000 \\
\hline & & Week 12 & $22.6 \%$ & 0.070 \\
\hline & \multirow[t]{3}{*}{ Niacinamide $5 \%$} & Post-application & $33.3 \%$ & 0.031 \\
\hline & & Week 8 & $0 \%$ & - \\
\hline & & Week 12 & $22.2 \%$ & 0.125 \\
\hline & \multirow[t]{3}{*}{ Vehicle } & Post-application & $30.6 \%$ & $<0.001$ \\
\hline & & Week 8 & $0 \%$ & 1.000 \\
\hline & & Week 12 & $8.2 \%$ & 0.375 \\
\hline
\end{tabular}


Table 3. Cont.

\begin{tabular}{ccccc}
\hline \multirow{2}{*}{ Endpoint } & Treatment & Time Point & $\begin{array}{c}\text { Subject } \\
\text { Improved \% }\end{array}$ & $p$ Value * \\
& SFC 1\% & Post-application & $90.3 \%$ & $<\mathbf{0 . 0 0 1}$ \\
& & Week 8 & $80.6 \%$ & $<\mathbf{0 . 0 1}$ \\
Texture (tactile) & Week 12 & $93.5 \%$ & $<\mathbf{0 . 0 0 1}$ \\
\cline { 2 - 5 } & Niacinamide 5\% & Post-application & $100.0 \%$ & $\mathbf{0 . 0 3 1}$ \\
& & Week 8 & $66.7 \%$ & $\mathbf{0 . 0 0 4}$ \\
& & Week 12 & $72.2 \%$ & $<\mathbf{0 . 0 0 1}$ \\
\cline { 2 - 5 } & Vehicle & Post-application & $95.9 \%$ & $<\mathbf{0 . 0 0 1}$ \\
& & Week 8 & $71.4 \%$ & $<\mathbf{0 . 0 0 1}$ \\
& & Week 12 & $75.5 \%$ & $<\mathbf{0 . 0 0 1}$
\end{tabular}

* Calculated using Wilcoxon signed rank test. Testing hypothesis is that the mean change from baseline is zero Numbers in bold indicate statistical significance ( $p$ value $<0.05) . p$ value $=1.000$, indicates the sample means between two groups are identical.

\section{Discussion}

The first IPC molecule, N-acetyl-S-farnesyl-L-cysteine (AFC) was discovered over 30 years ago [6,29], and was subsequently shown to effectively reduce edema and neutrophil infiltration when applied topically in in vivo animal models of inflammation and contact hypersensitivity [9]. Several other farnesyl-cysteine derivatives have been reported to successfully inhibit inflammation and oxidative stress release [21]. Moreover, another farnesylated IPC molecule, SIG-1191, has been shown to possess anti-inflammatory activity in NHEKs, and potential moisturizing activity when topically applied to 3D human skin [10]. Altogether, these results highlight the potential for this class of compounds to be utilized to ameliorate skin conditions and/or treat skin disease. Despite the promising in vitro and in vivo activity profile, no farnesylated IPC compound has been tested clinically for activity. Thus, we sought to determine for the first time the activity of farnesylated IPC N-Succinyl-S-farnesyl-L-cysteine (SFC) in a clinical study, and to begin to elucidate its mechanism of action to explain these benefits.

IPC molecules have been reported to modulate GPCRs, toll-like receptors (TLRs), and peroxisome proliferator-activated receptor gamma (PPAR- $\gamma$ ) signaling [30]; however, the mechanism of these anti-inflammatory effects is not well understood. Utilizing dermal microvascular endothelial cells, AFC was previously shown to inhibit purinergic GPCR inflammatory signaling (ATP-P2Y receptor-induced cytokine release) [31]. Moreover, SIG-1191 was shown to control the expression of skin hydration marker aquaporin 3 (AQP3) via the mitogen-activated protein kinase/extracellular signal-regulated kinase (MEK) pathway [10]. Moreover, IPC compounds SIG-1273 and SIG-1459 regulate TLR and T-cell receptor (TCR) signaling, which play an important role in the pathogenesis of acne and atopic dermatitis [11,12]. Here, we show that SFC modulates GPCR-FPRL1 signaling by successfully blocking cathelicidin (LL-37)-induced FPRL1 pro-inflammatory release in HDMECs. By specifically targeting inflammatory mediators released by HDMECs, SFC may be a potent inhibitor of chronic inflammation, as IL-6 plays a significant role in several cutaneous mechanisms and disorders, including wound healing [32]. Furthermore, epithelial cell-derived inflammatory mediators have been suggested to play a role in rosacea and psoriasis by LL-37 [33,34], which is an important effector molecule in these skin diseases, as well as atopic dermatitis [20]. As reported here, both anti-inflammatory rosacea drugs metronidazole $\left(\mathrm{IC}_{50}=14 \mu \mathrm{M}\right)$ and azelaic acid $\left(\mathrm{IC}_{50}=100 \mu \mathrm{M}\right)$, as well as atopic dermatitis treatment FK-506 $\left(\mathrm{IC}_{50}=1 \mu \mathrm{M}\right)$, reduce LL-37-FPRL1-induced cytokine release with differing potencies. SFC displays similar potency to FK-506, outperforms both rosacea drug compounds, and inhibits FPRL-1-induced ROS release (Figure 1A) from neutrophils. Altogether, these data demonstrate the ability of IPC molecules to interact on multiple different signaling pathways and cell types critical for skin inflammation. To this end, over the last $\sim 20$ years, TLR2 has emerged as a critical receptor in inflammatory 
skin disorders such as acne, rosacea, atopic dermatitis, and others [27,35-37]. Expressed in our skin, TLR2 is part of our first line of host immune defense in response to invading pathogens. TLR2 signaling works upstream of the GPCRs, TCR, and PPAR previously shown to be modulated by IPC analogs. Results presented here demonstrate that SFC potently inhibits PGN-TLR2-induced IL-8 release from NHEKs (Figure 2B), and successfully reduces TPA-induced TNF- $\alpha$ release in keratinocytes (Figure 2A). TPA is a known activator of protein kinase $C(P K C)$, which also plays a critical role in GPCR signaling. Thus, SFC may also inhibit the inflammatory signaling response downstream of PKC-induced cytokine release in NHEKs.

Chronic inflammation is a key player in driving both skin disease and aging. As reported here, in addition to inhibiting GPCR and TLR-induced inflammatory signaling, SFC also blocks UVB and UVA-induced inflammation, as well as MMP-1 production in fibroblasts, which degrades collagen and accelerates skin aging [22]. MMP-1 production is regulated by increasing MAP kinase/AP-1 activity [38]. Given the ability of SFC to provide anti-inflammatory activity in keratinocytes and endothelial cells, and slow oxidative stress and photo-aging in neutrophils and dermal fibroblasts, we hypothesized that SFC's broad spectrum of activity would be beneficial to human skin when applied topically. The clinical data presented here demonstrates that $1 \%$ SFC gel significantly reduces wrinkles, improves hydration, skin texture, skin brightening, and overall healthy skin appearance better than the vehicle. These results are especially exciting, given that most cosmetic clinical studies are performed without a vehicle control. Furthermore, SFC's skin health promoting properties in certain instances shows significant improvement over $5 \%$ niacinamide, a cosmetic anti-aging and anti-inflammatory benchmark ingredient (Table 3). While additional studies remain to be performed to further elucidate the mechanism of action of SFC as it relates to skin inflammation and aging, we propose here a working hypothesis of how SFC confers its skin health promoting activities regulating several targets, including TLR and GPCR signaling (Figure 4). Altogether, these results demonstrate SFC clinically improves signs of aging, and may be effective in improving skin health and combating several inflammatory dermal disorders.

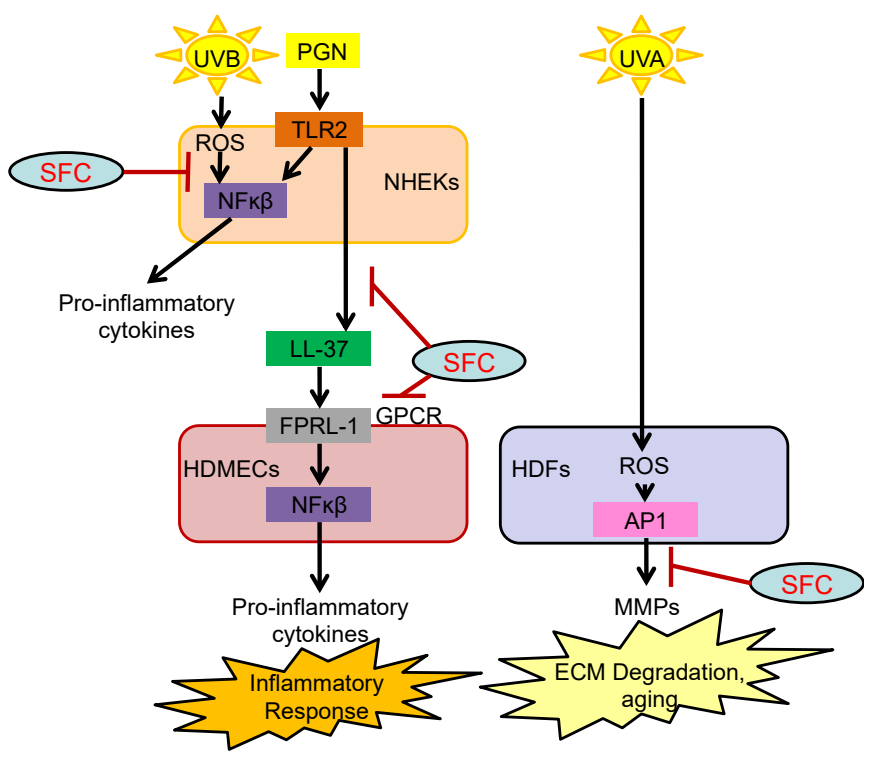

Figure 4. Proposed mechanism of action of SFC to reduce skin inflammation and slow aging. N-Succinyl-S-Farnesyl-L-cysteine (SFC); ultraviolet light A (UVA); ultraviolet light B (UVB); peptidoglycan (PGN); toll-like receptor 2 (TLR2); nuclear factor kappa-light-chain-enhancer of activated B cells (NF-kB); Normal Human Epidermal Keratinocytes (NHEKs); Cathelicidin (LL-37); g-protein coupled receptor (GPCR); formyl peptide receptor-like 1 (FPRL-1); Human dermal microvascular endothelial cells (HDMECs); Reactive Oxygen Species (ROS); Activator Protein 1 (AP1); matrix metalloproteinases (MMPs); extracellular matrix (ECM). 
Supplementary Materials: The following are available online at https:/ / www.mdpi.com/article/ 10.3390/ cosmetics8040110/s1, Figure S1: Chemical structure of SFC, Figure S2: Cell viability of cultured cells after $24 \mathrm{~h}$ incubation with SFC; Supplementary Table S1: Clinical formulation ingredient lists.

Author Contributions: Conceptualization, J.R.F., J.B.S. and E.P.; methodology, J.R.F. and J.B.S.; validation, J.R.F. and E.P.; formal analysis, J.R.F. and E.P.; investigation, J.R.F., K.R., C.F., J.H., M.T., and M.V.; resources, J.R.F., K.R. and E.P.; data curation, J.R.F.; writing-original draft preparation, J.R.F. and E.P.; writing-review and editing, J.R.F., K.R., C.F., J.H., M.T., M.V., J.B.S., M.S. and E.P.; visualization, J.R.F., C.F. and E.P.; supervision, J.B.S., M.S. and E.P. All authors have read and agreed to the published version of the manuscript.

Funding: This research received no external funding.

Institutional Review Board Statement: The study was conducted in accordance with all applicable guidelines for the protection of human subjects for research, as outlined in International Council for Harmonization (ICH) E6(R2), and accepted standards for Good Clinical Practice (GCP), and the standard practices of SGS Stephens and 701 Research, Inc., in accordance with the protocol and amendment(s) as applicable.

Informed Consent Statement: Informed consent was obtained from all subjects involved in the study.

Conflicts of Interest: J.R.F., K.R., C.F., J.H., M.T., M.V., M.S. and E.P. are employees. J.B.S. serves on the board of directors. All authors have stock and/or stock options in the company.

\section{References}

1. Marshall, C.J. Protein prenylation: A mediator of protein-protein interactions. Science 1993, 259, 1865-1866. [CrossRef]

2. Kloog, Y.; Cox, A.D. Prenyl-binding domains: Potential targets for Ras inhibitors and anti-cancer drugs. Semin. Cancer Biol. 2004, 14, 253-261. [CrossRef] [PubMed]

3. Fogg, V.C.; Azpiazu, I.; Linder, M.E.; Smrcka, A.; Scarlata, S.; Gautam, N. Role of the gamma subunit prenyl moiety in G protein beta gamma complex interaction with phospholipase Cbeta. J. Biol. Chem. 2001, 276, 41797-41802. [CrossRef] [PubMed]

4. Dietrich, A.; Scheer, A.; Illenberger, D.; Kloog, Y.; Henis, Y.I.; Gierschik, P. Studies on G-protein alpha.betagamma heterotrimer formation reveal a putative S-prenyl-binding site in the alpha subunit. Biochem. J. 2003, 376 Pt 2, 449-456. [CrossRef]

5. Regazzi, R.; Sasaki, T.; Takahashi, K.; Jonas, J.C.; Volker, C.; Stock, J.B.; Takai, Y.; Wollheim, C.B. Prenylcysteine analogs mimicking the C-terminus of GTP-binding proteins stimulate exocytosis from permeabilized HIT-T15 cells: Comparison with the effect of Rab3AL peptide. Biochim. Biophys. Acta 1995, 1268, 269-278. [CrossRef]

6. Volker, C.; Miller, R.A.; McCleary, W.R.; Rao, A.; Poenie, M.; Backer, J.M.; Stock, J.B. Effects of farnesylcysteine analogs on protein carboxyl methylation and signal transduction. J. Biol. Chem. 1991, 266, 21515-21522. [CrossRef]

7. Philips, M.R.; Pillinger, M.H.; Staud, R.; Volker, C.; Rosenfeld, M.G.; Weissmann, G.; Stock, J.B. Carboxyl methylation of Ras-related proteins during signal transduction in neutrophils. Science 1993, 259, 977-980. [CrossRef]

8. Huzoor-Akbar; Wang, W.; Kornhauser, R.; Volker, C.; Stock, J.B. Protein prenylcysteine analog inhibits agonist-receptor-mediated signal transduction in human platelets. Proc. Natl. Acad. Sci. USA 1993, 90, 868-872. [CrossRef] [PubMed]

9. Gordon, J.S.; Wolanin, P.M.; Gonzalez, A.V.; Fela, D.A.; Sarngadharan, G.; Rouzard, K.; Perez, E.; Stock, J.B.; Stock, M.B. Topical $\mathrm{N}$-acetyl-S-farnesyl-L-cysteine inhibits mouse skin inflammation, and unlike dexamethasone, its effects are restricted to the application site. J. Investig. Dermatol 2008, 128, 643-654. [CrossRef]

10. Fernández, J.R.; Webb, C.; Rouzard, K.; Voronkov, M.; Huber, K.L.; Stock, J.B.; Stock, M.; Gordon, J.S.; Perez, E. NAcetylglutaminoyl-S-farnesyl-L-cysteine (SIG-1191): An anti-inflammatory molecule that increases the expression of the aquaglyceroporin, aquaporin-3, in human keratinocytes. Arch. Dermatol. Res. 2017, 309, 103-110. [CrossRef]

11. Fernandéz, J.R.; Rouzard, K.; Voronkov, M.; Huber, K.L.; Stock, J.B.; Stock, M.; Gordon, J.S.; Pérez, E. Anti-inflammatory and anti-bacterial properties of tetramethylhexadecenyl succinyl cysteine (TSC): A skin-protecting cosmetic functional ingredient. Int. J. Cosmet. Sci. 2015, 37, 129-133. [CrossRef] [PubMed]

12. Fernández, J.R.; Webb, C.; Rouzard, K.; Healy, J.; Tamura, M.; Voronkov, M.; Huber, K.L.; Stock, J.B.; Stock, M.; Gordon, J.S.; et al. SIG1459: A novel phytyl-cysteine derived TLR2 modulator with in vitro and clinical anti-acne activity. Exp. Dermatol. 2018, 27, 993-999. [CrossRef] [PubMed]

13. Fernandéz, J.R.; Rouzard, K.; Voronkov, M.; Feng, X.; Stock, J.B.; Stock, M.; Gordon, J.S.; Shroot, B.; Christensen, M.S.; Pérez, E. SIG1273: A new cosmetic functional ingredient to reduce blemishes and Propionibacterium acnes in acne prone skin. J. Cosmet. Dermatol. 2012, 11, 272-278. [CrossRef]

14. Fernández, J.R.; Rouzard, K.; Voronkov, M.; Huber, K.L.; Webb, C.; Stock, J.B.; Stock, M.; Gordon, J.S.; Pérez, E. In vitro and clinical evaluation of SIG1273: A cosmetic functional ingredient with a broad spectrum of anti-aging and antioxidant activities. J. Cosmet. Dermatol. 2016, 15, 150-157. [CrossRef] [PubMed] 
15. Gierschik, P.; Steisslinger, M.; Sidiropoulos, D.; Herrmann, E.; Jakobs, K.H. Dual Mg2+ control of formyl-peptide-receptor-Gprotein interaction in HL 60 cells. Evidence that the low-agonist-affinity receptor interacts with and activates the G-protein. Eur. J. Biochem. 1989, 183, 97-105. [CrossRef] [PubMed]

16. Levy, R.; Rotrosen, D.; Nagauker, O.; Leto, T.L.; Malech, H.L. Induction of the respiratory burst in HL-60 cells. Correlation of function and protein expression. J. Immunol. 1990, 145, 2595-2601.

17. Dorward, D.A.; Lucas, C.D.; Chapman, G.B.; Haslett, C.; Dhaliwal, K.; Rossi, A.G. The role of formylated peptides and formyl peptide receptor 1 in governing neutrophil function during acute inflammation. Am. J. Pathol. 2015, 185, 1172-1184. [CrossRef]

18. Su, S.B.; Gong, W.; Gao, J.L.; Shen, W.; Murphy, P.M.; Oppenheim, J.J.; Wang, J.M. A seven-transmembrane, G protein-coupled receptor, FPRL1, mediates the chemotactic activity of serum amyloid A for human phagocytic cells. J. Exp. Med. 1999, 189, 395-402. [CrossRef] [PubMed]

19. Marzano, A.V.; Ortega-Loayza, A.G.; Heath, M.; Morse, D.; Genovese, G.; Cugno, M. Mechanisms of Inflammation in NeutrophilMediated Skin Diseases. Front Immunol. 2019, 10, 1059. [CrossRef] [PubMed]

20. Reinholz, M.; Ruzicka, T.; Schauber, J. Cathelicidin LL-37: An antimicrobial peptide with a role in inflammatory skin disease Ann. Dermatol. 2012, 24, 126-135. [CrossRef] [PubMed]

21. Ding, J.; Lu, D.J.; Pérez-Sala, D.; Ma, Y.T.; Maddox, J.F.; Gilbert, B.A.; Badwey, J.A.; Rando, R.R. Farnesyl-L-cysteine analogs can inhibit or initiate superoxide release by human neutrophils. J. Biol. Chem. 1994, 269, 16837-16844. [CrossRef]

22. Brennan, M.; Bhatti, H.; Nerusu, K.C.; Bhagavathula, N.; Kang, S.; Fisher, G.J.; Varani, J.; Voorhees, J.J. Matrix metalloproteinase-1 is the major collagenolytic enzyme responsible for collagen damage in UV-irradiated human skin. Photochem. Photobiol. 2003, 78, 43-48. [CrossRef]

23. Fisher, G.J.; Kang, S.; Varani, J.; Bata-Csorgo, Z.; Wan, Y.; Datta, S.; Voorhees, J.J. Mechanisms of photoaging and chronological skin aging. Arch. Dermatol. 2002, 138, 1462-1470. [CrossRef]

24. Paz, M.L.; Ferrari, A.; Weill, F.S.; Leoni, J.; Maglio, D.H.G. Time-course evaluation and treatment of skin inflammatory immune response after ultraviolet B irradiation. Cytokine 2008, 44, 70-77. [CrossRef]

25. Kim, S.; Kim, Y.; Kim, J.E.; Cho, K.H.; Chung, J.H. Berberine inhibits TPA-induced MMP-9 and IL-6 expression in normal human keratinocytes. Phytomedicine 2008, 15, 340-347. [CrossRef] [PubMed]

26. Cataisson, C.; Pearson, A.J.; Tsien, M.Z.; Mascia, F.; Gao, J.-L.; Pastore, S.; Yuspa, S.H. CXCR2 ligands and G-CSF mediate PKCalpha-induced intraepidermal inflammation. J. Clin. Investig. 2006, 116, 2757-2766. [CrossRef]

27. Miller, L.S. Toll-like receptors in skin. Adv. Dermatol. 2008, 24, 71-87. [CrossRef] [PubMed]

28. Bissett, D.L.; Oblong, J.E.; Berge, C.A. Niacinamide: AB vitamin that improves aging facial skin appearance. Dermatol. Surg. 2005, 31 Pt 2, 860-865, discussion 865. [CrossRef]

29. Tan, E.W.; Pérez-Sala, D.; Cañada, F.J.; Rando, R.R. Identifying the recognition unit for G protein methylation. J. Biol. Chem. 1991, 266, 10719-10722. [CrossRef]

30. Bhalla, K.; Hwang, B.J.; Choi, J.H.; Dewi, R.; Ou, L.; Mclenithan, J.; Twaddel, W.; Pozharski, E.; Stock, J.; Girnun, G.D. NAcetylfarnesylcysteine is a novel class of peroxisome proliferator-activated receptor gamma ligand with partial and full agonist activity in vitro and in vivo. J. Biol. Chem. 2011, 286, 41626-41635. [CrossRef] [PubMed]

31. Adhami, K.; Lee, J.; Levin, L.; Moquete, R.; Stohl, L.L.; Ding, W.; Wong, J.; Schierl, M.; Zhou, X.K.; Gordon, J.S.; et al. N-acetyl-Sfarnesyl-1-cysteine suppresses chemokine production by human dermal microvascular endothelial cells. Exp. Dermatol. 2012, 21, 700-705. [CrossRef]

32. Johnson, B.Z.; Stevenson, A.W.; Prêle, C.M.; Fear, M.W.; Wood, F.M. The Role of IL-6 in Skin Fibrosis and Cutaneous Wound Healing. Biomedicines 2020, 8, 101. [CrossRef] [PubMed]

33. Yoon, S.H.; Hwang, I.; Lee, E.; Cho, H.J.; Ryu, J.H.; Kim, T.G.; Yu, J.W. Antimicrobial Peptide LL-37 Drives Rosacea-Like Skin Inflammation in an NLRP3-Dependent Manner. J. Investig. Dermatol. 2021, 131, 2885-2894. [CrossRef] [PubMed]

34. Morizane, S.; Gallo, R.L. Antimicrobial peptides in the pathogenesis of psoriasis. J. Dermatol. 2012, 39, 225-230. [CrossRef]

35. Kim, J.; Ochoa, M.T.; Krutzik, S.R.; Takeuchi, O.; Uematsu, S.; Legaspi, A.J.; Brightbill, H.D.; Holland, D.; Cunliffe, W.J.; Akira, S.; et al. Activation of toll-like receptor 2 in acne triggers inflammatory cytokine responses. J. Immunol. 2002, 169, 1535-1541. [CrossRef]

36. Kaesler, S.; Volz, T.; Skabytska, Y.; Köberle, M.; Hein, U.; Chen, K.M.; Guenova, E.; Wölbing, F.; Röcken, M.; Biedermann, T. Toll-like receptor 2 ligands promote chronic atopic dermatitis through IL-4-mediated suppression of IL-10. J. Allergy Clin. Immunol. 2014, 134, 92-99. [CrossRef]

37. Yamasaki, K.; Kanada, K.; Macleod, D.T.; Borkowski, A.W.; Morizane, S.; Nakatsuji, T.; Cogen, A.L.; Gallo, R.L. TLR2 expression is increased in rosacea and stimulates enhanced serine protease production by keratinocytes. J. Investig. Dermatol. 2011, 131, 688-697. [CrossRef] [PubMed]

38. Wang, X.Y.; Bi, Z.G. UVB-irradiated human keratinocytes and interleukin-1alpha indirectly increase MAP kinase/AP-1 activation and MMP-1 production in UVA-irradiated dermal fibroblasts. Chin. Med. J. 2006, 119, 827-831. [CrossRef] [PubMed] 